\title{
Measurement of Air Flow Outside a Burning Cigarette during a Puff using Particle Image Velocimetry*
}

by

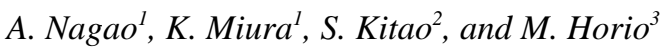

${ }^{I}$ Tobacco Science Research Center, Japan Tobacco Inc., Yokohama, Japan

${ }^{2}$ Research and Development Planning Division, Japan Tobacco Inc., Tokyo, Japan

${ }^{3}$ Tokyo University of Agriculture and Technology, Tokyo, Japan

\section{SUMMARY}

In order to clarify the mechanism for the generation of cigarette smoke, the combustion mechanism of a burning cigarette during a puff was investigated by focusing on air transfer. In particular, the air flow distribution outside a burning cigarette was observed and related to the aerodynamic effects of the cigarette paper and the puffing rate. The air flow rate was measured by Particle Image Velocimetry (PIV), using olive oil droplets as the tracer particles. It was found that air does not flow into the tip of the burning cigarette and that the air flow was concentrated at the region -2 to $2 \mathrm{~mm}$ around the cigarette paper char-line. This behavior was independent of the cigarette paper basis weight. When the puffing rate was changed from 2.5 to $35 \mathrm{~mL} / \mathrm{s}$, the air flow was concentrated at a region close to the cigarette paper char-line and the maximum velocity around the cigarette paper char-line increased with the puffing rate. [Beitr. Tabakforsch. Int. 21 (2004) 216-222]

\section{ZUSAMMENFASSUNG}

Um mehr über die Mechanismen zu erfahren, die der Entstehung des Zigarettenrauchs zu Grunde liegen, wurden die Verbrennungsmechanismen einer brennenden Zigarette während eines Zuges unter besonderer Berücksichtigung des Transfers von Luftströmungen untersucht. Insbesondere wurden die Strömungsverteilungen außerhalb der brennenden Zigarette beobachtet und zu den aerodynamischen Wirkungen der Zigarettenpapiers und der Zuggeschwindigkeit in Beziehung gesetzt. Die Strömungsgeschwindigkeit der Luft wurde durch Geschwindigkeitsmessung der Partikel, ,Particle Image Velocimetry“ (PIV), gemessen, wobei Oliven- öltröpfchen als Indikatorpartikel verwendet wurden. Es wurde festgestellt, dass keine Luft in die Spitze einer brennenden Zigarette strömt und dass der Luftstrom sich auf eine Region von $-2 \mathrm{~mm}$ bis $2 \mathrm{~mm}$ um die Brennlinie das Zigarettenpapiers konzentriert. Dieses Verhalten war unabhängig vom Gewicht des verwendeten Papiers. Bei Zunahme der Zuggeschwindigkeit von 2.5 auf $35 \mathrm{~mL} / \mathrm{s}$, konzentrierte sich der Luftstrom um eine Region nahe der Brennlinie des Zigarettenpapiers und die maximale Geschwindigkeit des Luftstroms um die Brennlinie des Papiers nahm mit der Zugrate zu. [Beitr. Tabakforsch. Int. 21 (2004] 216-222]

\section{RESUME}

Pour mieux comprendre le mécanisme de génération de la fumée de cigarette, le processus de combustion d'une cigarette a été examiné en prenant en considération les transferts de flux. En particulier, la distribution des flux d'air à l'extérieur d'une cigarette en combustion a été observée et mise en relation avec les effets aérodynamiques du papier à cigarette et du régime de bouffées. Le débit d'air a été mesuré par analyse vélocimétrique des particules, dénommé «Particle Image Velocimetry (PIV)», en utilisant des gouttes d'huile d'olive comme traceur. Il a été observé que les flux d'air n'entrent pas dans le bout d'une cigarette incandescente et que les flux d'air ont été concentrés à une région de $-2 \mathrm{~mm}$ à $2 \mathrm{~mm}$ autour de la ligne de carbonisation du papier. Ce comportement est indépendant du poids de base du papier à cigarette. Quand le régime de bouffées est changé de 2.5 à 35 $\mathrm{mL} / \mathrm{s}$, le flux d'air se concentre à une région près de la ligne de carbonisation du papier à cigarette et la vélocité maximale autour de la ligne de carbonisation augmente avec le taux de bouffées. [Beitr. Tabakforsch. Int. 21 (2004) 216-222] 


\section{INTRODUCTION}

For a long time, controlling the taste and odor of the cigarette mainstream smoke has been an interesting but delicate and difficult issue. Leaving aside the matter of the tobacco leaf quality, the taste and odor also depend strongly on the burning rate and on the filtering of the smoke by the tobacco bed and the filter during a puff. The burning rate is affected by the puffing regime, the bed structure, and the properties of the cigarette paper and cut tobacco. The details of cigarette burning have been investigated over decades but have not been completely clarified because of the difficulties in making the necessary measurements.

EGERTON et al. (1) studied the combustion mechanism during a puff. They used an X-ray method to record the temperatures of small inert particles as a function of position in the cigarette, and measured peripheral radiation temperatures. They concluded that almost all the air enters the cigarette around the periphery. Using an optical fiber pyrometer and thermocouple, BAKER (2) determined the transient change of temperature distribution in the burning region of the cigarette during a puff. BAKER (3) also measured the concentration distributions of oxygen and other gases inside a burning cigarette during a puff by sampling the gases inside the burning cigarette with a syringe inserted, which was connected directly to a mass spectrometer. He showed that the maximum solid-phase temperatures are located close to the char-line during a puff, and it was presumed that the air also flows into the region exhibiting the maximum solid-phase temperatures. From numerical analysis of a cigarette smoked under a steady-draw condition, SUMMERFIELD et al. (4) numerically analyzed the burning rate and pressure drop of a cigarette smoked under a steady-draw condition. From the results of the numerical analysis, they showed that the air enters the cigarette from the region near the char-line during a puff. However, the air inlet position during a puff was not completely identified and there have been no reports in respect of the measurement of the air flow distribution outside a burning cigarette during a puff.

Many reports have presented data on the temperature of the tobacco bed as a function of the puffing rate. Many of them (5-8) have indicated that the temperature on the surface of the cigarette coal increases as the puffing rate increased. MURAMATSU et al. (9) reported that the maximum temperature along the central axis of a cigarette does not change when the puffing rate increases. On the other hand, it is commonly known that 'tar' (nicotine-free dry particulate matter), nicotine and some other components in mainstream smoke increase with an increase of the puffing rate (10). Therefore, these results imply that changing the air supply to the cigarette coal surface should influence the burning rate.

Limited by experimental methods, previous reports have few data concerning the transient changes of the air flow distribution around a cigarette during a puff. If we can obtain its axial distribution, we can generate further understanding of the combustion mechanism of the cigarette during a puff and the maximum burning rate region can be identified in more detail. Furthermore, if the air flow distribution can be directly measured, the effects of the cigarette paper and the puffing rate on the burning rate of the tobacco bed during a puff can be understood more thoroughly. To clarify such transient behavior of the air flow field around a cigarette, we applied a Particle Image Velocimetry (PIV) technique to the system. We also focused on the effects of the cigarette paper and the puffing rate on the air flow field around a cigarette.

\section{EXPERIMENTAL}

Figure 1a shows the experimental set-up to measure the axial distribution of the air flow rate outside a burning cigarette during a puff. PIV (SLI-PIV, Continuum Co.) was applied to obtain the air flow rate distribution. PIV is a method that determines the air flow distribution by analyzing particle tracks compiled from two successive pictures taken within small time intervals. A laser beam from a frequency doubled Nd:Yag laser (wavelength $562 \mathrm{~nm}$ ) was used as the light source. The size of the chamber, which was made from acryl, was $0.3 \mathrm{~m}$ (width) by $0.35 \mathrm{~m}$ (length) by $0.4 \mathrm{~m}$ (height) and the bottom was left open so as to insert the charged coupled device (CCD) camera (XC$75 \mathrm{CE}$, Sony Co.). The picture size was $0.02 \mathrm{~m}$ (horizontal) by $0.014 \mathrm{~m}$ (vertical). In order to avoid that the burning cigarette being exposed to the laser beam and the burning rate of the cigarette changed, a shade plate was set in front of the chamber. The cigarette was placed at the center of the chamber and the direction of the cigarette axis was varied. When measuring the air flow distribution around the tip of the cigarette, the burning cigarette was placed at a right-angle to the laser beams (Figure 1b). On the other hand, when measuring the air flow distribution around the side, the burning cigarette was placed in parallel to the laser beams (Figure 1c). All measurements were done at $22{ }^{\circ} \mathrm{C}$ and $60 \%$ RH.

Atomized olive oil particles were used as tracers. Dry air was mixed with the olive oil by an atomizer and introduced into a chamber to produce particles of nearly equal size by allowing the larger particles to sink to the bottom of the chamber. The produced olive oil particles were introduced into the side of the acrylic chamber with the cigarette. The concentration of olive oil particles in the measurement chamber was adjusted so that more than 20 particles per $1 \mathrm{~cm}^{2}$ could be observed by the camera. The air flow distribution was measured at 1 to $3 \mathrm{~mm}$ from the side of the cigarette in the radial direction, and (the burning side) to $6 \mathrm{~mm}$ (the non-burning side) from the char-line in the axial direction. Since the flash and boiling points of olive oil are approximately 225 and $300{ }^{\circ} \mathrm{C}$, respectively, it was assumed that the olive oil would not be ignited or evaporated at 1 to $3 \mathrm{~mm}$ from the side of the cigarette in the radial direction. Moreover, since PIV is used to monitor the velocity components parallel to the laser sheet, velocity components orthogonal with respect to this plane cannot be measured. Since natural convection affects particles, it would destroy the rotational symmetry of the burning cigarette if the laser axis were not parallel to gravity. In this study, it was assumed that the particles are not affected by natural convection and only the air flow distributions at the same position from the bottom of the cigarette were evaluated as shown in Figures $1 \mathrm{~b}$ and 1c. An image was recorded every 0.1 seconds during puffing. Three sets of 


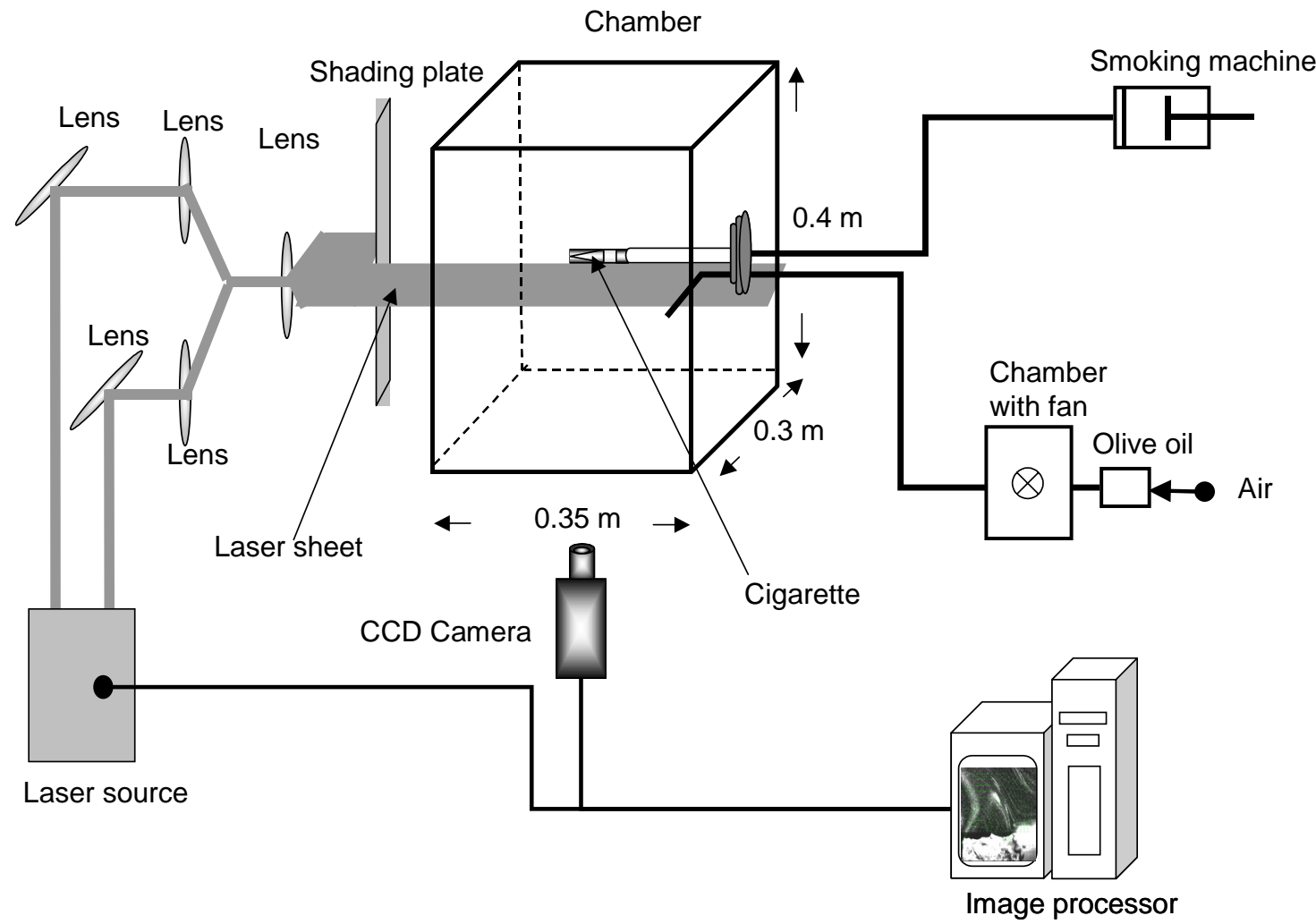

Figure 1a. Experimental set-up for measuring the air flow distribution of a burning cigarette during a puff

(b)

(3)

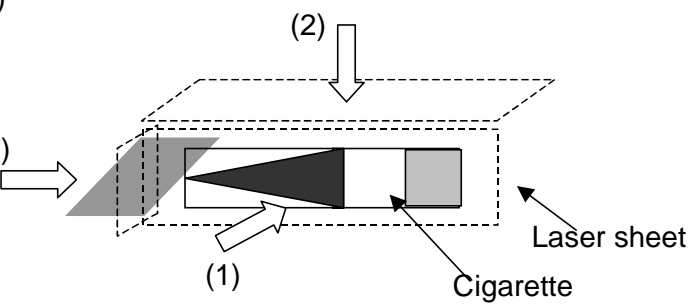

(1) View from side of cigarette

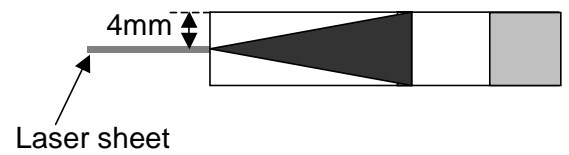

(2) View from top of cigarette

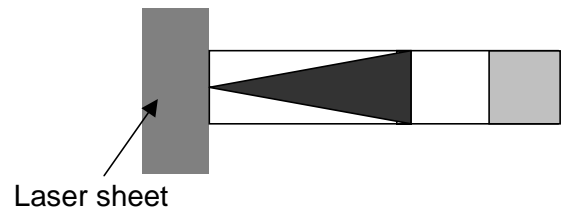

(3) View from tip of cigarette

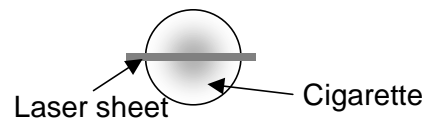

Figure 1b. Set-up for measuring the tip flow distribution of a cigarette (c)

(3)

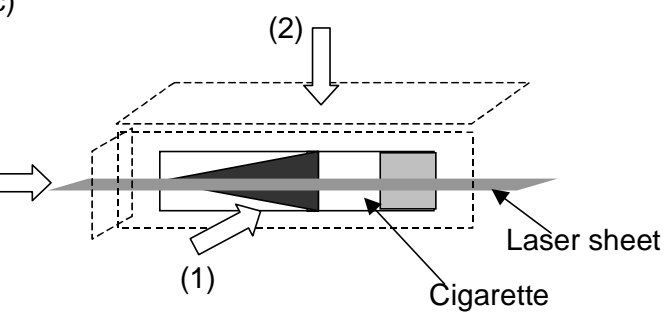

(1) View from side of cigarette

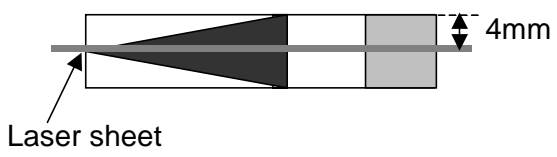

(2) View from top of cigarette

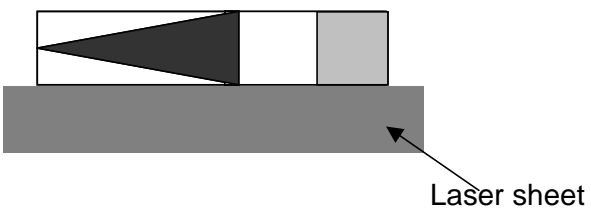

(3) View from tip of cigarette

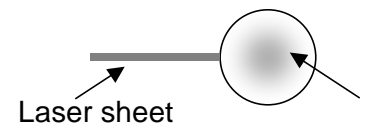

Figure 1c. Set-up for measuring the side flow distribution of a cigarette 


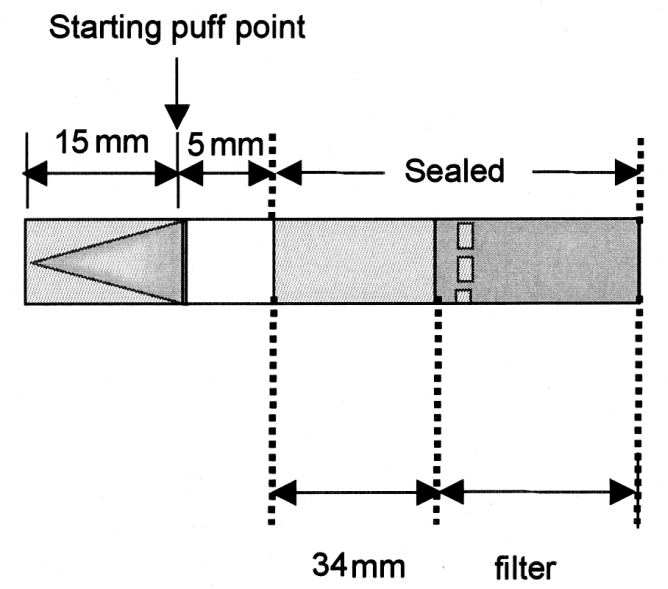

Figure 2. Cigarette set-up for measurements

data for each cigarette variation or condition were taken and the air flow rate was determined from the average of the three sets of data.

The cigarette set-up for the measurements is shown in Figure 2. The cigarette was smoldered without puffing for $15 \mathrm{~mm}$ after ignition and then it was puffed singly at a constant rate by a smoking machine (RGA-System R26: Borgwaldt Technik GmbH). To avoid the effects of air flowing through the non-burning cigarette paper and the ventilation from the filter, $34 \mathrm{~mm}$ from the end of the cigarette paper were sealed by impervious tape.

The design specifications of the test cigarettes are shown in Table 1 . The sample cigarettes were $8 \mathrm{~mm}$ in diameter, $0.23 \mathrm{~g} / \mathrm{cm}^{3}$ in tobacco density. The same tobacco blend was used for all the samples. The inside of the filter section was empty. The paper permeability for the two samples was the same. There was a difference in $\mathrm{CO}, \mathrm{CO}_{2}$, nicotine and 'tar' yields per puff. This indicates that the burning rates of cigarettes A and B should be different. The basis weight of the cigarette paper, which affects the yield of major components in mainstream smoke as shown in Table 1, is different for two cases and there is also a small difference in burn additive content (potassium citrate). The puffing rate was varied from 2.5 to $35 \mathrm{~mL} / \mathrm{s}$ for cigarette A. Corresponding to the varied puffing rate, the time interval was changed as shown in Table 2.
Table 2. Applied time intervals between two photographs for each puffing rate

\begin{tabular}{lc}
\hline Puffing rate $(\mathrm{mL} / \mathrm{s})$ & Camera shutter speed $(\mu \mathrm{s} /$ measurement $)$ \\
\hline 2.5 & 7000 \\
3.75 & 4666 \\
5.0 & 3500 \\
6.5 & 2700 \\
8.75 & 2000 \\
17.5 & 1000 \\
27.5 & 650 \\
\hline
\end{tabular}

\section{RESULTS AND DISCUSSION}

\section{The region where air enters a burning cigarette}

Figures $3 \mathrm{a}$ and $3 \mathrm{~b}$ are photographs showing the tracks of particles. Figure 3 a shows the air flow vectors around the tip of cigarette A during a puff and Figure $3 \mathrm{~b}$ shows the flow vectors around the side of cigarette $\mathrm{A}$ at $1 \mathrm{~s}$ after the start of the puff for the puffing rate of $17.5 \mathrm{~mL} / \mathrm{s}$. From Figure $3 \mathrm{a}$, it can be seen that air does not flow into the tip of the cigarette coal. This was confirmed experimentally for all the samples and all the puffing conditions. From Figure $3 \mathrm{~b}$, it can be observed that air entered the cigarette from the side of the burning cigarette.

Figure 4 shows the distribution of the air flow velocity outside a burning cigarette at $0.5,1$ and $1.5 \mathrm{~s}$ after the start of the puff for cigarette A. The thick black line shows the char-line at each time. From Figure 4, it can be seen that the air flow is always concentrated near the char-line during a puff. BAKER (11) reported that the viscous air flow resistance of the tip of the cigarette coal is higher than of the unburned tobacco bed because of its high temperature. As the unburned tobacco bed is still wrapped with the cigarette paper, which acts as an additional resistance to air flow, most of the air effectively enters the cigarette through a slit between the coal and the unburned tobacco bed. This agrees with the air flow velocity distributions shown in Figures 3 and 4 . On the other hand, the flow velocity distribution can be obtained only at regions away from the side of the ciga-

Table 1. Design specification of cigarette samples (tobacco density: $0.23 \mathrm{~g} / \mathrm{cm}^{3}$, circumference: $25 \mathrm{~mm}$ )

\begin{tabular}{|c|c|c|c|c|c|c|c|c|}
\hline \multirow[b]{2}{*}{ Cigarettes } & \multicolumn{4}{|c|}{ Cigarette paper } & \multicolumn{4}{|c|}{ 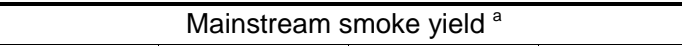 } \\
\hline & $\begin{array}{c}\text { Basis weight } \\
\left(\mathrm{g} / \mathrm{m}^{2}\right)\end{array}$ & $\begin{array}{c}\text { Filler } \\
(\%)\end{array}$ & $\begin{array}{c}\text { Burn additive } \\
(\%)^{b}\end{array}$ & $\begin{array}{c}\text { Permeability } \\
(\mathrm{CU})^{\mathrm{c}}\end{array}$ & $\begin{array}{c}\mathrm{CO} \\
\text { (mg/puff) }\end{array}$ & $\begin{array}{c}\mathrm{CO}_{2} \\
\text { (mg/puff) }\end{array}$ & $\begin{array}{l}\text { Nicotine } \\
\text { (mg/puff) }\end{array}$ & $\begin{array}{c}\text { 'Tar' } \\
\text { (mg/puff) }\end{array}$ \\
\hline Cigarette A & 22.5 & 39.6 & 1.0 & 35.0 & 2.0 & 8.2 & 0.17 & 1.4 \\
\hline Cigarette B & 40.0 & 40.0 & 0.0 & 35.0 & 3.3 & 11.3 & 0.20 & 1.6 \\
\hline
\end{tabular}

\footnotetext{
${ }^{a}$ Mainstream smoke yield at smoking regime of singly $35 \mathrm{~mL}$ puff of $2 \mathrm{~s}$ duration to a butt length $39 \mathrm{~mm}$ after the cigarette was smoldered without puffing for $15 \mathrm{~mm}$, as shown in Figure 2.

${ }^{\mathrm{b}}$ Potassium citrate.

${ }^{c}$ CORESTA unit (CU) is the air permeability unit $\left(\mathrm{cm}^{3} / \mathrm{min} / \mathrm{cm}^{2}\right)$, which can be obtained by measuring the flow of air (cm $\left.3 / \mathrm{min}\right)$ passing through $1 \mathrm{~cm}^{2}$ surface of the test piece at a measuring pressure of $1 \mathrm{kPa}$.
} 

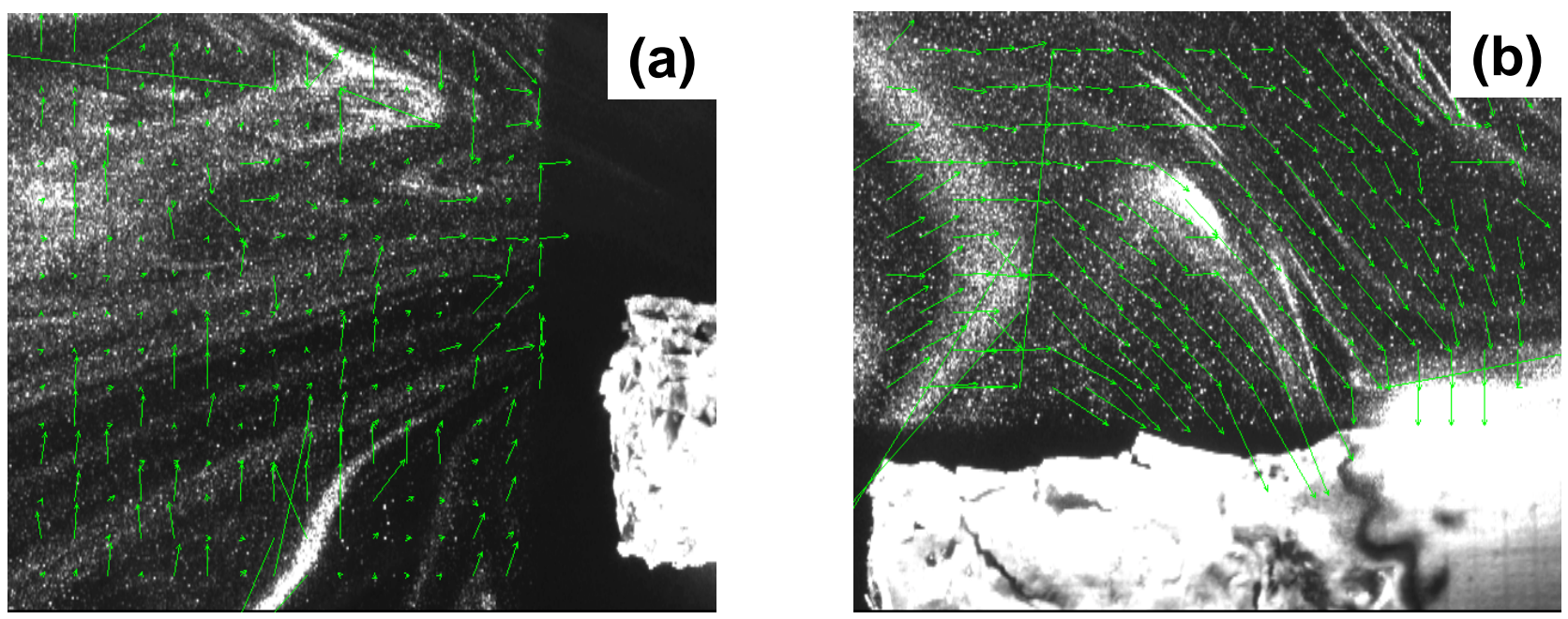

Figure 3. Photographs of the flow distribution during a puff around the tip and side of cigarette $A$ at $1 \mathrm{~s}$ after the puff starts

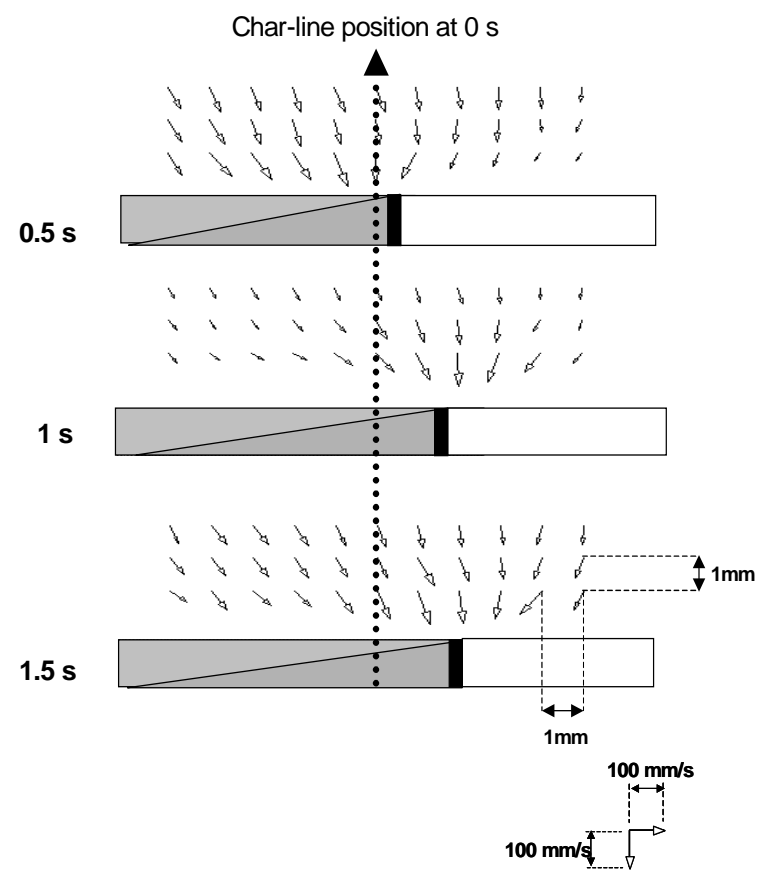

Figure 4. Flow distribution around the side of cigarette $A$ at $0.5,1,1.5 \mathrm{~s}$ after the puff starts

cigarette. Since the air flow vectors are more concentrated closer to the surface of the cigarette paper, those on the surface near the paper char-line should be larger than the vectors at the regions away from the cigarette (Figure 4).

\section{Effect of cigarette paper characteristics}

Figure 5 shows the air flow distributions of cigarettes A and $\mathrm{B}$ at $1 \mathrm{~s}$ after the start of the puff for a puffing rate of $17.5 \mathrm{~mL} / \mathrm{s}$. The air flow vectors around the burning cigarette were concentrated to the char-line for the two samples. No significant differences were observed for

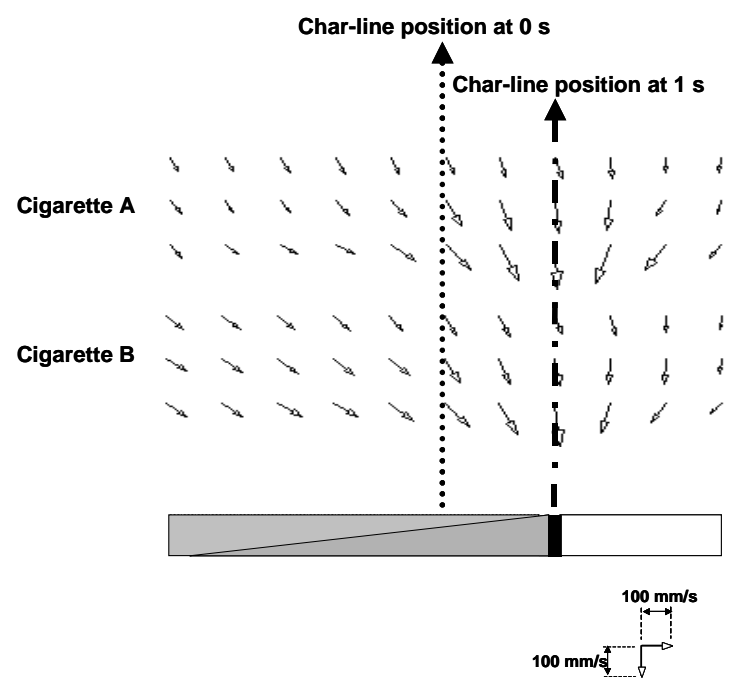

Figure 5. Flow distribution around the side of cigarettes $A$ and $B$ at $1 \mathrm{~s}$ after the puff starts

cigarettes A and B. The length $V$ of the velocity vector at each position was introduced by $\left(V_{\text {axial }}{ }^{2}+V_{\text {radial }}{ }^{2}\right)^{1 / 2}$, where $V_{\text {axial }}$ and $V_{\text {radial }}$ are axial and radial flow velocities, respectively. Figure 6 shows the length $V$ at $1 \mathrm{~mm}$ from the side of cigarettes A and B at $1 \mathrm{~s}$ after the start of the puff. The positive domain in the horizontal abscissa corresponds to the non-burning area and the negative domain to the burning area. No significant difference was observed between cigarettes $\mathrm{A}$ and $\mathrm{B}$. The main difference between cigarettes A and B is the basis weight of the cigarette paper. This indicates that none of the properties related to and caused by the cigarette paper basis weight such as the paper ash permeability influence the flow velocity distribution. On the other hand, since air enters the cigarette through the region close to the paper char-line during a puff, the burning rate of cigarette paper should influence the position of the air inflow into the tobacco bed. If the burning rate of cigarette paper is relatively slow, the amount of air drawn 


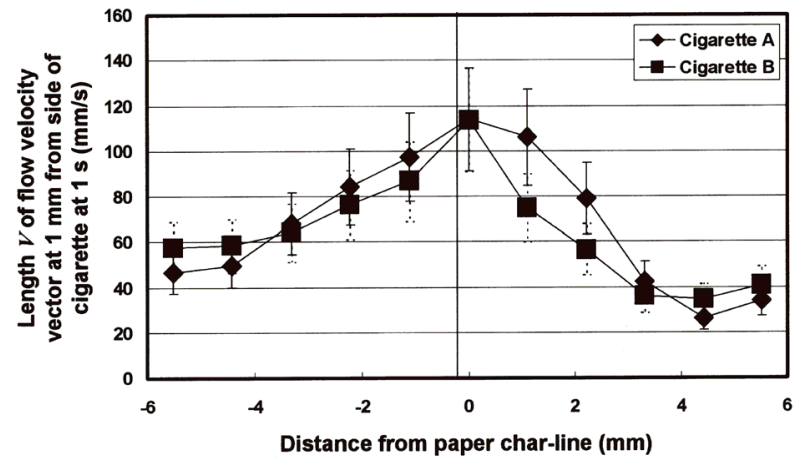

Figure 6. Length $V$ of the velocity vector at $1 \mathrm{~s}$ after the puff starts for the puffing rate of $17.5 \mathrm{~mL} / \mathrm{s}$ at $1 \mathrm{~mm}$ from the side of cigarettes A and B

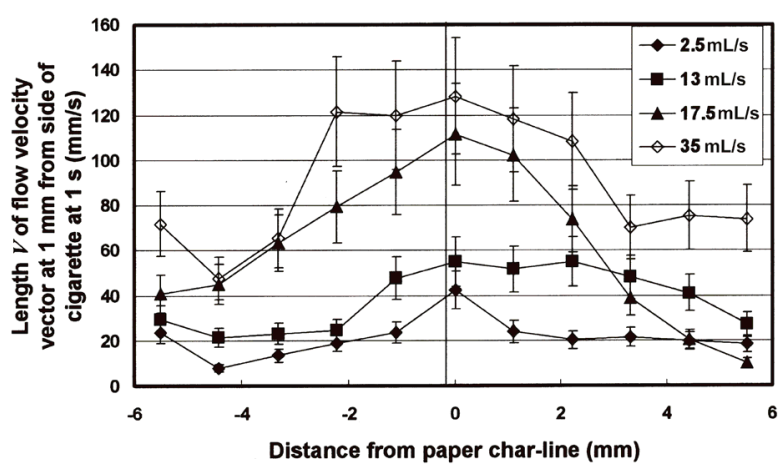

Figure 7. Length $V$ of the velocity vector at $1 \mathrm{~mm}$ from the side of cigarette $A$ at $1 \mathrm{~s}$ after the puff starts for puffing rates of $2.5,13,17.5$ and $27.5 \mathrm{~mL} / \mathrm{s}$

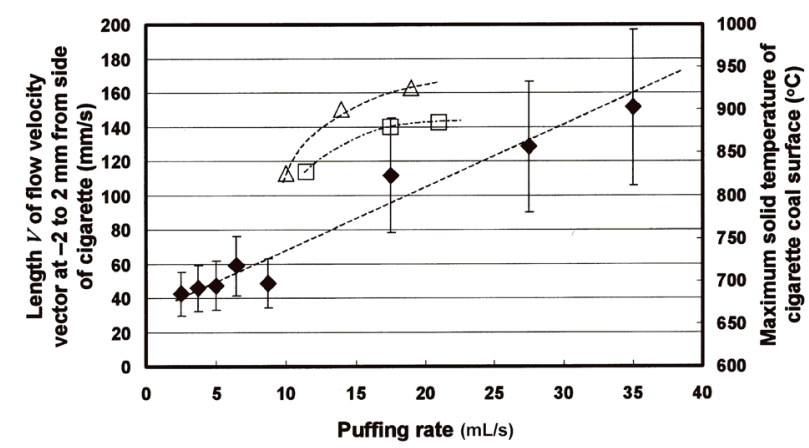

Figure 8. Maximum length $V$ of -2 to $2 \mathrm{~mm}$ from the char-line at $1 \mathrm{~s}$ after the puff starts and the maximum temperature on the surface of cigarette coal reported by LENDVAY and LASZLO (6) and BAKER (8) for puffing rates from 2.5 to $27.5 \mathrm{~mL} / \mathrm{s}$. ( maximum velocity; $\quad \square=$ maximum solid temperature of cigarette coal surface by LENDVAY and LASZLO (6); $\triangle$ = maximum solid temp. of cigarette coal surface by BAKER (8))

into the high temperature tobacco bed will be relatively high. This should cause an increase of the burning rate of the tobacco bed during a puff. Therefore, we conclude that the burning rate of the cigarette paper affects the burning rate of the tobacco bed during a puff.

\section{Effect of puffing rates}

Figure 7 shows the length $V$ of the velocity vector at $1 \mathrm{~mm}$ from the side of cigarette $\mathrm{A}$, at $1 \mathrm{~s}$ after the start of the puff for four puffing rates. Experimental errors in the length $V$ were high for values -6 to -2 and 2 to $6 \mathrm{~mm}$ because the difference between the flow created by natural convection and the flow rate into the cigarette is small in these regions. It was observed that the air flow was concentrated closer to the char-line with increasing puffing rate. By limiting observations from -2 to $2 \mathrm{~mm}$, it is seen that the length $V$ increases with the puffing rate. To investigate this region in more detail, we show the maximum length $V$ of the velocity vector of -2 to $2 \mathrm{~mm}$ at $1 \mathrm{~s}$ after the start of the puff in the left ordinate of Figure 8, when the puffing rate is changed. The maximum air velocity increased with the puffing rate. The LENDVAY data (6) and BAKER data (8) on the maximum temperature of the cigarette coal surface during a puff is also shown in Figure 8. The data indicate that the maximum temperature on the surface of the cigarette coal increases with the puffing rate. Therefore, it is concluded that the increase of air velocity into the tobacco bed near the paper char-line causes the increase of temperature of the surface of the cigarette coal.

\section{CONCLUSIONS}

In order to clarify the transient behavior of the air flow field around a cigarette during a puff, the distribution of the air flow rate outside a burning cigarette was directly measured using Particle Image Velocimetry (PIV). The dominant factors in determining the burning rate during a puff, i.e. the cigarette paper properties and the puffing rates, were investigated in terms of their effects on the air flow field around a cigarette.

It was found that air does not flow into the tip of the burning cigarette but into its side. The air flow was always concentrated to the char-line during puffing. This was confirmed for all the samples and all the puffing rates in the present study. This agreed with previous presumptions, which are that the air enters the cigarette through the region close to the paper char-line. The cigarette paper basis weight affected the air flow distribution around a cigarette only slightly. The maximum air flow rate around the charline increased with the puffing rate.

\section{ACKNOWLEDGEMENT}

We gratefully acknowledge the help and advice that Dr. M. Inagaki, Mr. K. Katayama and Dr. Y. Yamada of Tobacco Science Research Center, Japan Tobacco INC., gave us in using PIV.

\section{REFERENCES}

1. Egerton, S.A., K. Gugan, and F.J. Weinberg: The mechanism of smouldering in cigarettes; Combust. Flame 7 (1963) 63-78.

2. Baker, R.R.: Temperature variation within a cigarette combustion coal during the smoking cycle; High Temp. Sci. 7 (1975) 236-247.

3. Baker, R.R.: Variation of the gas formation regions within a cigarette combustion coal during the smoking 
cycle; Beitr. Tabakforsch. Int. 11 (1981) 1-17.

4. Summerfield, M., T.J. Ohlemiller, and H.W. Sandusky: A thermophysical mathematical model of steady-draw smoking and predictions of overall cigarette behavior; Combust. Flame 33 (1978) 263-279.

5. Donzel, M.: The influence of smoking conditions on the temperature of the glowing end of cigarettes: Cilitoxicity and composition of the gas phase; Ann. du Tabac 11 (1973) 45-57.

6. Lendvay, T.S. and T.S. Laszlo: Cigarette peak coal temperature measurements; Beitr. Tabakforsch. Int. 7 (1974) 276-281.

7. Baker, R.R.: Design of low tar cigarettes. The effect of ventilation on cigarette combustion mechanisms; Rec. Adv. Tob. Sci. 10 (1984) 88-150.

8. Baker, R.R.: Some burning problems in tobacco science; in: Proceedings of the International Conference on the physical and chemical processes occurring in a burning cigarette, Winston-Salem, NC, April 1987, pp. 1-61.

9. Muramatsu, M., T. Obi, T. Fukuzawa, and T. Keii: Influence of continuous puff velocity on combustion rate, temperature and temperature distribution of cigarette; Bio-Chemistry Japan 46 (1972) 569-572.
10. Borgerding, M.F.: The FTC method in 1997 - What alternative smoking condition(s) does the future hold?; Rec. Adv. Tob. Sci. 23 (1997) 75-151.

11. Baker, R.R.: Contributions to the draw resistance of a burning cigarette; Beitr. Tabakforsch. 8 (1975) 124-132.

Corresponding author:

Atsushi Nagao

Tobacco Science Research Center

Japan Tobacco Inc.

6-2, Umegaoka, Aoba-ku

Yokohama, Kanagawa 227-8512

Japan

E-mail:atsushi.nagao@ims.jti.co.jp 